\title{
DETERMINING THE SUPPLY CHAIN STRATEGY IN MARKETING WITH SWOT ANALYSIS AT PT INTERNIT GRESIK
}

\author{
AUTHOR \\ Moh Dian Kurniawan', ${ }^{1}$ Iksan $^{2}$ \\ Departement of Industrial Engineering, Faculty of Engineering, Universitas Muhammadiyah Gresik \\ Departement of Industrial Engineering, Faculty of Engineering, Universitas Qomaruddin, Gresik \\ md.kurniawan@umg.ac.id
}

\begin{abstract}
PT Eternit Gresik produces fiberglass which is currently experiencing a slight decline, because it provides an opportunity to create tight competitiveness in market share and challenges for the future. Researchers aim to determine the PT Enternit Gresik Supply Chain management strategy in the best marketing to face competition.

The method used in this study using a SWOT analysis, and AHP weighting with the help of spss software. This study produces a recommendation in the best marketing strategy for PT Eternit Gresik to use. The results of the SWOT analysis, it can be seen that the position of the company is located at the coordinate point $(-0.0636$; 0.0435) quadrant III which means it supports the turnaround strategy, namely the company faces a very large market opportunity, but on the other hand, it faces several internal constraints / weaknesses. Meanwhile, in the internal - external matrix with an internal value (2.1021) and an external value (2.1882), the position of growth stability is growth through horizontal integration. The growth strategy through horizontal integration is that companies in this cell can expand their market share, production facilities and technology through internal and external development. Can determine alternative strategies for Supply Chain management of PT Eternit Gresik's fiberglass production in marketing resulting in several alternative strategies, namely the growth strategy through horizontal integration by expanding market share, production facilities and technology through internal and external development. Minimizing the occurrence of the bullwhip effect, facilitating activity mapping along the value stram to minimize the occurrence of waste.
\end{abstract}

Keywords: Strategy, Supply chain management, matrix, SWOT, IFE EFE. Marketing, AHP

\section{Introduction}

In the last 2 centuries the industrial environment has changed very rapidly. Supported by the rapid development of technology and better supply chain management. Competition is not only between companies but also between supply chain management that is reliable and capable of responding to the market. The flow of globalization has increasingly hit almost all countries around the world. Competition between supply chains is increasingly intense, so each supply chain always analyzes and improves its performance and proper strategy in seizing and responding to the market so that it is able to compete with others. This inevitably brings companies in Indonesia into world-class competition, competitors are not only limited to domestic but also global competition.

In the current era of globalization, technology is also developing and the industrial world is growing. One of the industries in Indonesia that has an important role and has a fairly high competitiveness in the midst of the domestic market is a company engaged in fiberglass products. The products produced by PT Eternit Gresik have been marketed to several areas, namely Semarang, Solo, Magelang. Even outside the island, namely Kalimantan. However, the competition in fiberglass products is getting tougher. Therefore the company should evaluate at any time to find out the problems that exist and find the right solution to solve the problem. With this situation, this research was conducted to help make decisions. In this case, 
the company is able to make the right decisions, so that the strategies taken will be able to provide optimum benefits for the company.

Research purposes

a) Knowing the performance condition of PT Eternit Gresik's Supply Chain management in marketing by applying the AHP \& SWOT Analysis Method

b) Measuring the performance of Supply Chain management of PT Eternit Gresik's Fiberglass production in marketing by applying the AHP \& SWOT Analysis Method

c) Determine alternative Supply Chain management strategies in marketing Fiberglass PT Eternit Gresik

\section{Research Methods}

Supply Chain Management Supply Chain Management is an alternative strategy that provides solutions in the face of environmental uncertainty to achieve competitive advantage through reducing operating costs and improving customer service and customer satisfaction. The method used in this study using a SWOT analysis, and AHP weighting with the help of spss software.

\section{Result and Discussion}

a) Determination of Number of Samples

Determination of the number of samples is done by distributing the initial questionnaire which is to find out how many official questionnaires will later be distributed to respondents. After distributing the initial 30 questionnaires, it was found that 2 questionnaires were filled incorrectly, then a test was carried out to determine the number of official questionnaires using the following formula:

$$
\begin{aligned}
& \mathrm{N}^{\prime} \leq \mathrm{N} \quad \mathrm{P}=\frac{28}{30} \mathrm{e}=0.05 \\
& \mathrm{~N} \leq \frac{\left(Z_{\alpha / 2}\right)^{2} p q}{e^{2}} \quad \mathrm{q}=\frac{2}{30} \quad \mathrm{Z}_{\alpha / 2}=1.96 \\
& \mathrm{~N} \leq \frac{(1,96)^{2}(28 / 30)(2 / 30)}{(0.05)^{2}} \\
& \mathrm{~N} \leq 85,76 \approx 86 \text { Responden }
\end{aligned}
$$

b) Rating and Weighting Questionnaire

At this stage to determine the level of interest of the company and competitors. In processing data for ratings and weights, reliability and validity tests were not carried out, because the data were obtained from interviews with companies who really knew the condition of the company so that the data were considered valid.

c) alidity and Reliability Test

The data obtained from the overall distribution need to be tested for validity and reliability, test the validity and reliability of these attributes using SPSS software. And if there are attributes that are not valid and reliable, then improvements are made to the questionnaire that is distributed and redistributed to respondents, if after it is done it remains invalid and reliable then the attribute will be discarded. Using $=0.05$ which is 0.207 , from the questionnaire table for reliable customers. Then a new SWOT value rating table is created in AHP

d) Questionnaire assessment with AHP

The data processing is done manually using the AHP method, to evaluate the results of the questionnaire, the following values are obtained: 
1) . For external strategy factors

a. Weighting

\begin{tabular}{|c|c|c|c|c|c|c|c|c|c|c|}
\hline Strategi & $\mathbf{1}$ & $\mathbf{2}$ & $\mathbf{3}$ & $\mathbf{4}$ & $\mathbf{5}$ & $\mathbf{6}$ & $\mathbf{7}$ & $\mathbf{8}$ & $\mathbf{9}$ & $\mathbf{1 0}$ \\
\hline $\mathbf{1}$ & 1 & 2 & 3 & 3 & 4 & 2 & 2 & 1 & 3 & 3 \\
\hline $\mathbf{2}$ & 0.50 & 1 & 1 & 2 & 1 & 2 & 3 & 3 & 1 & 2 \\
\hline $\mathbf{3}$ & 0.33 & 1.00 & 1 & 1 & 2 & 3 & 3 & 2 & 1 & 1 \\
\hline $\mathbf{4}$ & 0.33 & 0.50 & 1.00 & 1 & 1 & 1 & 2 & 1 & 3 & 1 \\
\hline $\mathbf{5}$ & 0.25 & 1.00 & 0.50 & 1.00 & 1 & 1 & 3 & 4 & 1 & 2 \\
\hline $\mathbf{6}$ & 0.50 & 0.50 & 0.33 & 0.33 & 1.00 & 1 & 1 & 1 & 2 & 1 \\
\hline $\mathbf{7}$ & 0.50 & 0.33 & 0.33 & 0.50 & 0.33 & 1.0 & 1 & 1 & 1 & 1 \\
\hline $\mathbf{8}$ & 1.00 & 0.33 & 0.50 & 1.00 & 0.25 & 1.0 & 1.0 & 1 & 1 & 1 \\
\hline $\mathbf{9}$ & 0.33 & 1.00 & 1.00 & 0.33 & 1.00 & 0.5 & 1.0 & 1.0 & 1 & 2 \\
\hline $\mathbf{1 0}$ & 0.33 & 0.50 & 1.00 & 1.00 & 0.50 & 1.0 & 1.00 & 1.0 & 0.50 & 1 \\
\hline \hline Jumlah & 5.1 & 8.2 & 9.7 & 11.2 & 12.1 & 13.5 & 18.0 & 16.0 & 14.5 & 15.0 \\
\hline
\end{tabular}

b. Normalization matrix

\begin{tabular}{|c|c|c|c|c|c|c|c|c|c|c|c|c|}
\hline Strategi & 1 & 2 & 3 & 4 & 5 & 6 & 7 & 8 & 9 & 10 & Jumlah & Bobot \\
\hline 1 & 0.1960 & 0.2439 & 0.3092 & 0.2678 & 0.3305 & 0.1481 & 0.1111 & 0.0625 & 0.2068 & 0.2000 & 2.0759 & 0.2075 \\
\hline 2 & 0.0980 & 0.1219 & 0.1030 & 0.1785 & 0.0826 & 0.1481 & 0.1667 & 0.1875 & 0.0689 & 0.1333 & 1.2885 & 0.1288 \\
\hline 3 & 0.0647 & 0.1219 & 0.1030 & 0.0892 & 0.1652 & 0.2222 & 0.1667 & 0.1250 & 0.0689 & 0.0667 & 1.1935 & 0.1193 \\
\hline 4 & 0.0647 & 0.0609 & 0.1030 & 0.0892 & 0.0826 & 0.0740 & 0.1111 & 0.0625 & 0.2068 & 0.0667 & 0.9215 & 0.0921 \\
\hline 5 & 0.0490 & 0.1219 & 0.0515 & 0.0892 & 0.0826 & 0.0740 & 0.1667 & 0.2500 & 0.0689 & 0.1333 & 1.0871 & 0.1087 \\
\hline 6 & 0.0980 & 0.0609 & 0.0340 & 0.0294 & 0.0826 & 0.0740 & 0.0556 & 0.0625 & 0.1379 & 0.0667 & 0.7016 & 0.0701 \\
\hline 7 & 0.0980 & 0.0402 & 0.0340 & 0.0446 & 0.0272 & 0.0740 & 0.0556 & 0.0625 & 0.0689 & 0.0667 & 0.5717 & 0.0571 \\
\hline 8 & 0.1960 & 0.0402 & 0.0515 & 0.0892 & 0.0206 & 0.0740 & 0.0556 & 0.0625 & 0.0689 & 0.0667 & 0.7252 & 0.0725 \\
\hline 9 & 0.0647 & 0.1219 & 0.1030 & 0.0294 & 0.0826 & 0.0370 & 0.0556 & 0.0625 & 0.0689 & 0.1333 & 0.7589 & 0.0758 \\
\hline 10 & 0.0647 & 0.0609 & 0.1030 & 0.0892 & 0.0413 & 0.0740 & 0.0556 & 0.0625 & 0.0344 & 0.0667 & 0.6523 & 0.0652 \\
\hline
\end{tabular}

c. Comparison Matrix

\begin{tabular}{|c|c|c|c|c|c|c|c|c|c|c|c|}
\hline Strategi & $\mathbf{1}$ & $\mathbf{2}$ & $\mathbf{3}$ & $\mathbf{4}$ & $\mathbf{5}$ & $\mathbf{6}$ & $\mathbf{7}$ & $\mathbf{8}$ & $\mathbf{9}$ & $\mathbf{1 0}$ & Jumlah \\
\hline $\mathbf{1}$ & 0.2075 & 0.2576 & 0.3615 & 0.2790 & 0.4348 & 0.1402 & 0.1142 & 0.0725 & 0.2296 & 0.1975 & 2.2944 \\
\hline $\mathbf{2}$ & 0.1037 & 0.1288 & 0.1193 & 0.1842 & 0.1087 & 0.1402 & 0.1730 & 0.2196 & 0.0758 & 0.1304 & 1.3837 \\
\hline $\mathbf{3}$ & 0.0691 & 0.1288 & 0.1193 & 0.0921 & 0.2174 & 0.2124 & 0.1730 & 0.1450 & 0.0758 & 0.0652 & 1.2981 \\
\hline $\mathbf{4}$ & 0.0691 & 0.0644 & 0.1193 & 0.0921 & 0.1087 & 0.0701 & 0.1142 & 0.0725 & 0.2296 & 0.0652 & 1.1475 \\
\hline $\mathbf{5}$ & 0.0518 & 0.1288 & 0.0596 & 0.0921 & 0.1087 & 0.0701 & 0.1730 & 0.2900 & 0.0758 & 0.1304 & 1.1803 \\
\hline $\mathbf{6}$ & 0.1037 & 0.0644 & 0.0397 & 0.0921 & 0.1087 & 0.0701 & 0.0571 & 0.0725 & 0.1516 & 0.0652 & 0.8251 \\
\hline $\mathbf{7}$ & 0.1037 & 0.0429 & 0.0397 & 0.0460 & 0.0363 & 0.0701 & 0.0571 & 0.0725 & 0.0758 & 0.0652 & 0.6093 \\
\hline $\mathbf{8}$ & 0.2075 & 0.0429 & 0.0596 & 0.0921 & 0.0271 & 0.0701 & 0.0571 & 0.0725 & 0.0758 & 0.0652 & 0.7699 \\
\hline $\mathbf{9}$ & 0.0691 & 0.1288 & 0.1193 & 0.0307 & 0.1081 & 0.0350 & 0.0571 & 0.0725 & 0.0758 & 0.1304 & 0.8274 \\
\hline $\mathbf{1 0}$ & 0.0691 & 0.0644 & 0.1193 & 0.0921 & 0.0543 & 0.0701 & 0.0571 & 0.0725 & 0.0379 & 0.0652 & 0.7020 \\
\hline
\end{tabular}

d. Determine the eigenvector

\begin{tabular}{|c|c|c|c|}
\hline Strategy & Number of matrices & Weight & Quotient \\
\hline $\mathbf{1}$ & & & 11.0573 \\
\hline $\mathbf{2}$ & 2.2944 & 0.2075 & 10.7430 \\
\hline $\mathbf{3}$ & 1.3837 & 0.1288 & 10.8809 \\
\hline $\mathbf{5}$ & 1.2981 & 0.1193 & 12.4592 \\
\hline $\mathbf{6}$ & 1.1475 & 0.0921 & 10.8583 \\
\hline $\mathbf{8}$ & 1.1803 & 0.1087 & 11.7703 \\
\hline $\mathbf{9}$ & 0.8251 & 0.0701 & 10.6707 \\
\hline $\mathbf{1 0}$ & 0.6093 & 0.0571 & 10.6193 \\
\hline $\mathbf{y}$ & 0.7699 & 0.0725 & 10.9155 \\
\hline
\end{tabular}

Finding the maximum value 


$$
\begin{aligned}
& \lambda_{\text {maks }}=\frac{\text { Eigenvector }}{n} \\
= & \frac{11.0573+10.7430+10.8809+10.8946+12.4592+10.8583+11.7703+10.6707+10.6193+10.7668}{10}=\frac{110.7413}{10}=11.0741
\end{aligned}
$$

f. Looking for index consistency value

$$
C I=\frac{\lambda_{m a k s}-n}{n-i}=\frac{11.0741-10}{9}=\frac{0.1193}{9}=0.0132
$$

g. Looking for consistency ratio

$$
C R=\frac{C I}{R I}=\frac{0.0132}{1.49}=0.0088
$$

Shows that the consistency is good because CR $<0.1$

2) For internal strategy factors

From the Weighting, Normalization Matrix, Comparison Matrix, Determining the eigenvectors, the Sum and weight strategies are obtained as follows:

\begin{tabular}{|c|c|c|c|c|c|c|c|c|c|c|c|c|}
\hline \multicolumn{10}{|c|}{ Normalization matrix } \\
\hline Strategi & $\mathbf{1}$ & $\mathbf{2}$ & $\mathbf{3}$ & $\mathbf{4}$ & $\mathbf{5}$ & $\mathbf{6}$ & $\mathbf{7}$ & $\mathbf{8}$ & $\mathbf{9}$ & $\mathbf{1 0}$ & Jumlah & Bobot \\
\hline $\mathbf{1}$ & 0.1724 & 0.3061 & 0.1219 & 0.2912 & 0.1600 & 0.1538 & 0.1875 & 0.1333 & 0.0653 & 0.2222 & 1.8137 & 0.1813 \\
\hline $\mathbf{2}$ & 0.0568 & 0.1020 & 0.2439 & 0.0970 & 0.0800 & 0.0769 & 0.1250 & 0.2000 & 0.1307 & 0.0556 & 1.1679 & 0.1167 \\
\hline $\mathbf{3}$ & 0.1724 & 0.0510 & 0.1219 & 0.1941 & 0.2400 & 0.2307 & 0.0625 & 0.0667 & 0.1307 & 0.1111 & 1.3811 & 0.1381 \\
\hline $\mathbf{4}$ & 0.0568 & 0.1020 & 0.0609 & 0.0970 & 0.0800 & 0.1538 & 0.1875 & 0.2000 & 0.1960 & 0.0556 & 1.1896 & 0.1189 \\
\hline $\mathbf{5}$ & 0.0862 & 0.1020 & 0.0402 & 0.0970 & 0.0800 & 0.1538 & 0.0625 & 0.0667 & 0.0653 & 0.0556 & 0.8093 & 0.0809 \\
\hline $\mathbf{6}$ & 0.0862 & 0.1020 & 0.0402 & 0.0320 & 0.0400 & 0.0769 & 0.1250 & 0.1333 & 0.1307 & 0.1111 & 0.8774 & 0.0877 \\
\hline $\mathbf{7}$ & 0.0568 & 0.0510 & 0.1219 & 0.0320 & 0.0800 & 0.0384 & 0.0625 & 0.0667 & 0.0653 & 0.0556 & 0.6302 & 0.0630 \\
\hline $\mathbf{8}$ & 0.0862 & 0.0336 & 0.1219 & 0.0320 & 0.0800 & 0.0384 & 0.0625 & 0.0667 & 0.1307 & 0.1111 & 0.7631 & 0.0763 \\
\hline $\mathbf{9}$ & 0.1724 & 0.0510 & 0.0609 & 0.0320 & 0.0800 & 0.0384 & 0.0625 & 0.0333 & 0.0653 & 0.1667 & 0.7625 & 0.0762 \\
\hline $\mathbf{1 0}$ & 0.0431 & 0.1020 & 0.0609 & 0.0970 & 0.0800 & 0.0384 & 0.0625 & 0.0333 & 0.0215 & 0.0556 & 0.5943 & 0.0594 \\
\hline
\end{tabular}

\begin{tabular}{|c|c|c|c|c|c|c|c|c|c|c|c|}
\hline \multicolumn{10}{|c|}{ Comparison Matrix } \\
\hline Strategi & $\mathbf{1}$ & $\mathbf{2}$ & $\mathbf{3}$ & $\mathbf{4}$ & $\mathbf{5}$ & $\mathbf{6}$ & $\mathbf{7}$ & $\mathbf{8}$ & $\mathbf{9}$ & $\mathbf{1 0}$ & Jumlah \\
\hline $\mathbf{1}$ & 0.1813 & 0.3536 & 0.1381 & 0.3603 & 0.1618 & 0.1754 & 0.1909 & 0.1526 & 0.0762 & 0.2376 & 2.0278 \\
\hline $\mathbf{2}$ & 0.0604 & 0.1167 & 0.2762 & 0.1189 & 0.0809 & 0.0877 & 0.1260 & 0.2312 & 0.1524 & 0.0594 & 1.3098 \\
\hline $\mathbf{3}$ & 0.1813 & 0.0583 & 0.1381 & 0.2378 & 0.2451 & 0.2657 & 0.0630 & 0.0763 & 0.1524 & 0.1188 & 1.5368 \\
\hline $\mathbf{4}$ & 0.0604 & 0.1167 & 0.0690 & 0.1189 & 0.0809 & 0.1754 & 0.1909 & 0.2312 & 0.2309 & 0.0594 & 1.4240 \\
\hline $\mathbf{5}$ & 0.0906 & 0.1167 & 0.0460 & 0.1189 & 0.0809 & 0.1754 & 0.0630 & 0.0763 & 0.0762 & 0.0594 & 0.9034 \\
\hline $\mathbf{6}$ & 0.0906 & 0.1167 & 0.0460 & 0.0594 & 0.0404 & 0.0877 & 0.1260 & 0.1526 & 0.1524 & 0.1188 & 0.9906 \\
\hline $\mathbf{7}$ & 0.0604 & 0.0583 & 0.1381 & 0.0396 & 0.0809 & 0.0438 & 0.0630 & 0.0763 & 0.0762 & 0.0594 & 0.6960 \\
\hline $\mathbf{8}$ & 0.0906 & 0.0389 & 0.1381 & 0.0396 & 0.0809 & 0.0438 & 0.0630 & 0.0763 & 0.1524 & 0.1188 & 0.8424 \\
\hline $\mathbf{9}$ & 0.1813 & 0.0583 & 0.0690 & 0.0396 & 0.0809 & 0.0438 & 0.0630 & 0.0381 & 0.0762 & 0.1800 & 0.8302 \\
\hline $\mathbf{1 0}$ & 0.0453 & 0.1167 & 0.0690 & 0.1189 & 0.0809 & 0.0438 & 0.0630 & 0.0381 & 0.0254 & 0.0594 & 0.6605 \\
\hline
\end{tabular}

3). Determine the eigenvector

\begin{tabular}{|c|c|c|c|}
\hline \multicolumn{2}{|c|}{ Menentukan eigen vector } & Quotient \\
\hline Strategy & Number of matrices & Weight & 11.1847 \\
\hline $\mathbf{1}$ & 2.0278 & 0.1813 & 11.2236 \\
\hline $\mathbf{2}$ & 1.3098 & 0.1167 & 11.1281 \\
\hline $\mathbf{3}$ & 1.5368 & 0.1381 & 11.9764 \\
\hline $\mathbf{4}$ & 1.4240 & 0.1189 & 11.1668 \\
\hline $\mathbf{5}$ & 0.9034 & 0.0809 & 11.2953 \\
\hline $\mathbf{6}$ & 0.9906 & 0.0877 & 11.0476 \\
\hline $\mathbf{7}$ & 0.6960 & 0.0630 & 11.0406 \\
\hline $\mathbf{8}$ & 0.8424 & 0.0763 & 10.8950 \\
\hline
\end{tabular}




\begin{tabular}{|l|l|l|l|}
\hline $\mathbf{1 0}$ & 0.6605 & 0.0594 & 11.1195 \\
\hline
\end{tabular}

e. Finding the maximum value

$$
\lambda_{\text {maks }}=\frac{\text { Eigenvector }}{n}
$$

$=\frac{11.1847+11.2236+11.1281+11.9764+11.1668+11.2953+11.0476+11.0406+10.8950+11.1195}{10}=\frac{1120776}{10}=11.2077$

f. Looking for index consistency value

$$
C I=\frac{\lambda_{\text {maks }}-n}{n-i}=\frac{11.2077-10}{9}=\frac{1.2077}{9}=0.1341
$$

Looking for consistency ratio

$$
C R=\frac{C I}{R I}=\frac{0.1341}{1.49}=0.09
$$

Shows that the consistency is good because CR $<0.1$

Table 2. values weighted with AHP

\begin{tabular}{|c|l|c|}
\hline No & \multicolumn{1}{|c|}{ Variable } & Weight \\
\hline Factor Exsternal & 0.2075 \\
\hline 1 & Munculnya pesaing-pesaing baru & 0.1288 \\
\hline 2 & Permasalahan limbah juga berpengaruh & 0.1193 \\
\hline 3 & Teknologi yang digunakan pesaing lebih baik & 0.0921 \\
\hline 4 & Perubahan harga sangat berpengaruh & 0.1087 \\
\hline 5 & Ketersediaan kredit diperlukan & 0.0701 \\
\hline 6 & Kemungkinan memperluas pangsa pasar & 0.0571 \\
\hline 7 & Pengiriman produk ke distributor sesuai ketentuan & 0.0725 \\
\hline 8 & Pelanggan menyukai produk cv.kamas & 0.0758 \\
\hline 9 & Kecenderungan masyarakat membeli sudah baik & 0.0652 \\
\hline 10 & Apakah produk mampu bersaing & \\
\hline Factor Internal & 0.1813 \\
\hline 11 & Mesin produksi masih terbatas & 0.1167 \\
\hline 12 & Modal usaha Sudah memadai & 0.1381 \\
\hline 13 & Pesaing yang lebih bermutu dan berkualitas & 0.1189 \\
\hline 14 & Persediaan bahan baku & 0.0809 \\
\hline 15 & Harga produk berpengaruh & 0.0877 \\
\hline 16 & Cara promosi sudah baik & 0.0630 \\
\hline 17 & Adanya iklan juga mempengaruhu penjualan & 0.0763 \\
\hline 18 & Perubahan selera konsumen sangat berpengaruh & 0.0762 \\
\hline 19 & Adanya pelatihan-pelatihan tambahan kepada karyawan & 0.0594 \\
\hline 20 & Waktu penyelesain produk sudah tepat waktu & \multicolumn{1}{|c|}{} \\
\hline
\end{tabular}

\section{SWOT analysis}

This SWOT (Strength, Weakness, Opportunities, Treatment) analysis is based on the company's own assessment compared to competing companies. From the results of the weight assessment and rating results. After all the question variables from the four factors have been weighed, the next step is to determine the rating and score for each question variable. The determination of the rating value is carried out by the respondent at the time of filling out the second questionnaire (SWOT). Determination of the rating is done by giving a scale from 4 (Ousstanding) to 1 (Poor) based on the influence of these factors on the condition of the company. For opportunity, if the opportunity is greater, it is given a rating of 4 , but if the opportunity is small, 
it is given a rating of 1 . While the rating value for the threat factor is the opposite. The calculation of the score is done by multiplying the weight value by the rating value. Data from the calculation of weights, ratings, and scores for external strategic factors can be

Table 3. External Strategy Factors (EFAS)

\begin{tabular}{|c|c|c|c|}
\hline \multirow{2}{*}{ Faktor-faktor strategi eksternal } & \multirow{2}{*}{ Bobot } & \multicolumn{2}{|c|}{ Perusahaan } \\
\hline & & Rating & Bobot skor \\
\hline \multicolumn{4}{|l|}{ PELUANG } \\
\hline > Kemungkinan memperluas pangsa pasar & 0.0701 & 3.6 & 0.2524 \\
\hline$>$ Pengiriman produk ke distributor sesuai dengan ketentuan & 0.0571 & 3.5 & 0.1999 \\
\hline > Pelanggan menyukai produk cv.kamas & 0.0725 & 3.2 & 0.2320 \\
\hline > Kecenderungan masyarakat membeli sudah baik & 0.0758 & 3.2 & 0.2426 \\
\hline \multirow[t]{2}{*}{ > Apakah produk mampu bersaing } & \multirow[t]{2}{*}{0.0652} & \multirow[t]{2}{*}{2.9} & 0.1891 \\
\hline & & & 1.1159 \\
\hline ANCAMAN & & & \\
\hline$>$ Munculnya pesaing-pesaing baru & 0.2075 & 1.5 & 0.3113 \\
\hline
\end{tabular}

As for the internal strategy factor, the way to determine the rating and score for each question variable is the same as for the external strategy factor, namely by giving a scale from 4 (Ousstanding) to 1 (Poor) based on the influence of these factors on the company's condition. For strength, if the opportunity is greater, it is given a rating of 4 , but if the opportunity is small, it is given a rating of 1 . While the rating value for the weakness factor is the opposite.

Table 4. Internal Strategy Factors Table (IFAS)

\begin{tabular}{|c|c|c|c|}
\hline \multirow{2}{*}{ Faktor-faktor strategi internal } & \multirow{2}{*}{ Bobot } & \multicolumn{2}{|c|}{ Perusahaan } \\
\hline & & Rating & Bobot skor \\
\hline \multicolumn{4}{|l|}{ KEKUATAN } \\
\hline$>$ Cara promosi sudah baik & 0.0877 & 3 & 0.2631 \\
\hline$>$ Adanya iklan juga mempengaruhi penjualan & 0.0630 & 2.8 & 0.1764 \\
\hline$>$ Perubahan selera konsumen sangat berpengaruh & 0.0763 & 2.8 & 0.21364 \\
\hline$>$ Adanya pelatihan-pelatihan tambahan kepada karyawan & 0.0762 & 2.7 & 0.20574 \\
\hline \multirow[t]{2}{*}{ > Waktu penyelesain produk sudah tepat waktu } & \multirow[t]{2}{*}{0.0594} & \multirow[t]{2}{*}{2.7} & 0.16038 \\
\hline & & & 1.01926 \\
\hline \multicolumn{4}{|l|}{ KELEMAHAN } \\
\hline$>$ Mesin produksi masih terbatas & 0.1813 & 1.6 & 0.29008 \\
\hline$>$ Modal usaha sudah memadai & 0.1167 & 1.7 & 0.19839 \\
\hline$>$ Pesaing yang lebih bermutu dan berkualitas & 0.1381 & 1.7 & 0.23477 \\
\hline$>$ Persediaan bahan baku & 0.1189 & 1.8 & 0.21402 \\
\hline \multirow[t]{2}{*}{$>$ Harga produk berpengaruh } & 0.0809 & \multirow[t]{2}{*}{1.8} & 0.14562 \\
\hline & 1.0000 & & 1.08288 \\
\hline \multicolumn{3}{|c|}{ Total keseluruhan nilai internal } & 2.10214 \\
\hline
\end{tabular}

From the table of external strategy factors, it is known that the total score of opportunity factor for the company is 1.1159 . While the total score for the threat factor for the Company is 1.0724 . For the internal strategy factor, which can be seen in the table, it is known that the total score of the Company's strength factor is 1.0193. Meanwhile, the Company's weakness factor is 1.0829 .

Calculation for the value of External Factors:

Opportunity score - Threat score $=1.1159-1.0724=0.0435$

Calculation for the value of Internal Factors:

Strength Score - Weakness $=1.0193-1.0829=-0.0636$ 


\section{SWOT ANALYSIS DIAGRAM}

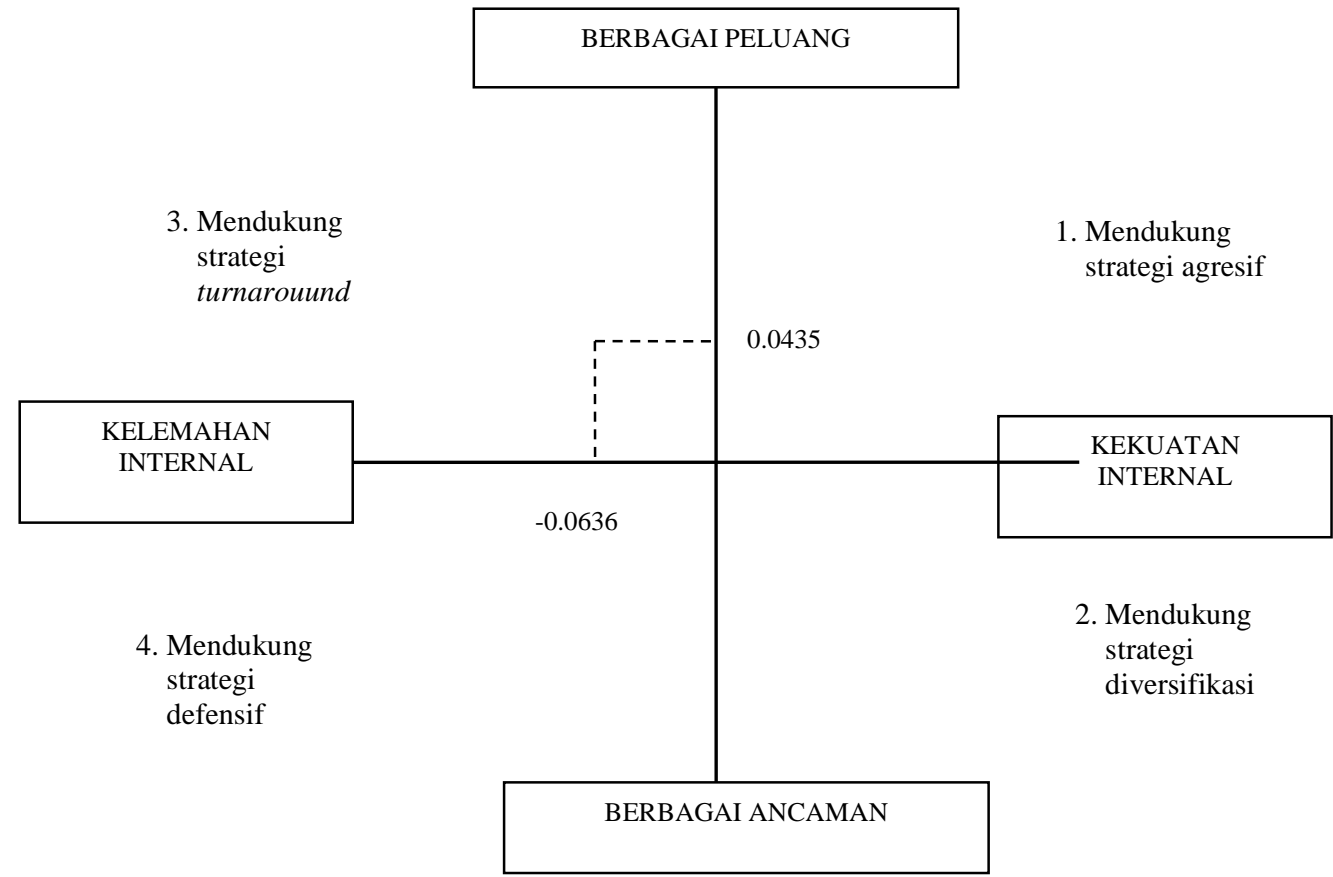

From the picture, it can be seen that the company's position is in Quadrant III, where in this quadrant the company faces huge market opportunities, but on the other hand, it faces several internal constraints/weaknesses. The focus of this strategy is to minimize the company's internal problems so that it can seize better market opportunities

\section{Internal External (IE) Matrix}

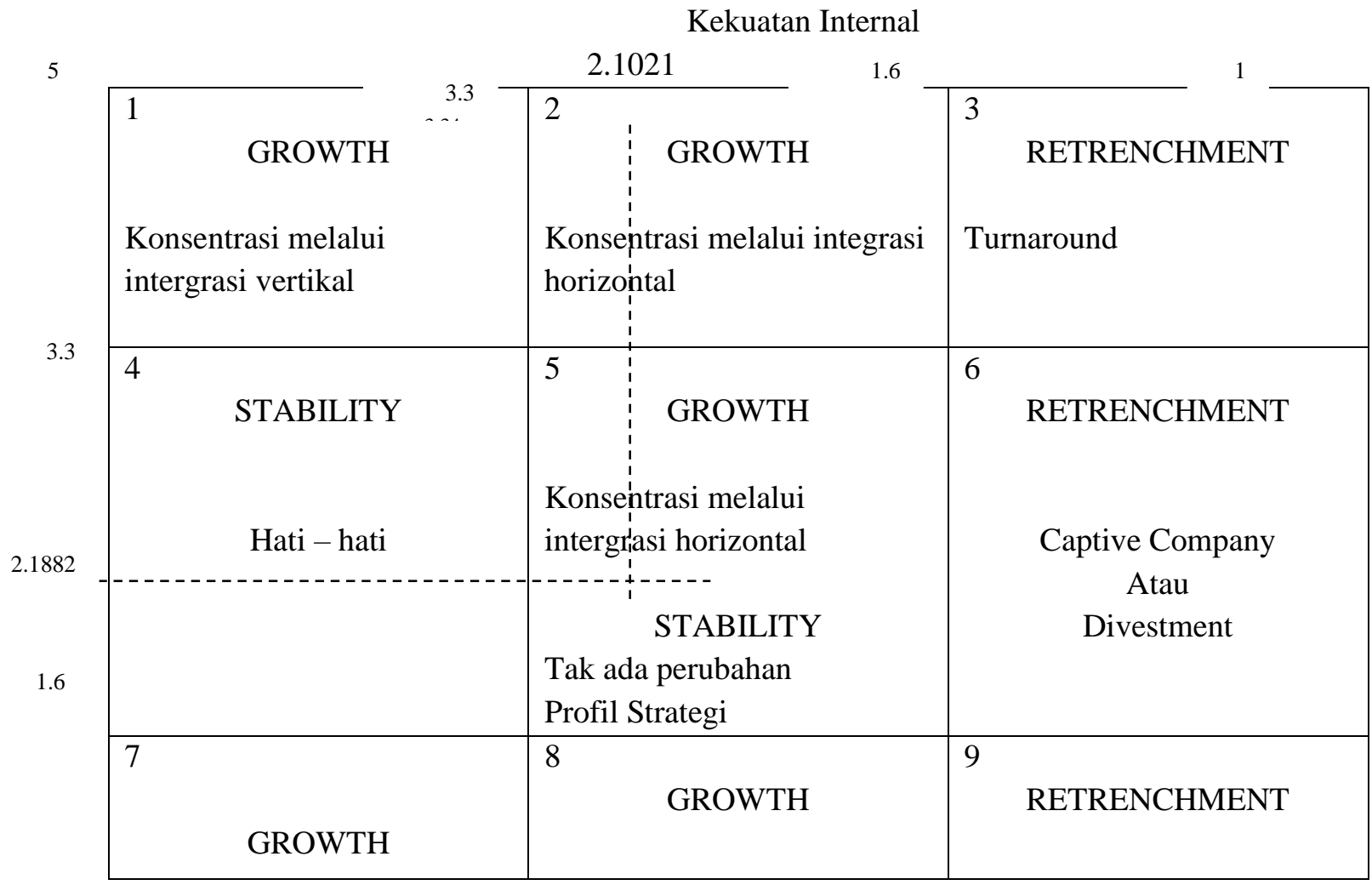




\begin{tabular}{|l|l|l|}
\hline Difersifikasi Konsentrik & Difersifikasi Konglomerat & $\begin{array}{l}\text { Bangkrut atau } \\
\text { Likuidasi }\end{array}$ \\
\hline
\end{tabular}

\section{Diagram MATRIK INTERNAL EKSTERNAL (IE)}

In the General Electric Matrix (Internal - External Matrix) the company is located at 2.1021 in the IFAS table and is located at 2.1882 in the EFAS table, this means that the Internal - External Matrix is in the Growth Stability position, namely growth through horizontal integration. Companies in this cell can expand market share, production facilities and technology through internal and external development.

\section{SWOT analysis}

Determining the right policy must begin with analyzing and diagnosing opportunities and threats in the environment. This is necessary so that the company is able to deal with situations and conditions in which the company carries out its business activities. Situation analysis is the beginning of the strategy formulation process. In addition, situation analysis also requires strategic managers to find a strategic fit between external opportunities and internal strengths, while also paying attention to external threats and internal weaknesses. Incorporation and analysis of the environment, analysis of strengths, and weaknesses within the company itself is usually known as a SWOT analysis, which stands for S (strength), W (weakness), O (opportunity), T (threat). External strategy factor is known that the total score of opportunity factor for the company is 1.1159. While the total score for the threat factor for the Company is 1.0724. For the internal strategy factor, which can be seen in table 4.8, it is known that the total value of the Company's strength factor score is 1.0193. Meanwhile, the Company's weakness factor is 1.0829.

Calculation for the value of External Factors:

Opportunity score - Threat score $=1.1159-1.0724=0.0435$

Calculation for the value of Internal Factors:

Strength Score - Weakness $=1.0193-1.0829=-0.0636$

This SWOT analysis is based on the company's own assessment compared to competing companies. From the results of the assessment of weights and ratings obtained results.

Table 5. Total internal and external weight and rating factors.

\begin{tabular}{|l|l|c|}
\hline \multicolumn{1}{|c|}{ No } & \multicolumn{1}{|c|}{ Faktor } & Total weightt $\mathrm{x}$ Rating \\
\hline 1. & Company internal Factor & 2.1021 \\
\hline 2. & Company External factor & 2.1882 \\
\hline
\end{tabular}

\section{SWOT Matrix}

The tool used to compile the company's strategic factors is the SWOT matrix. This matrix can clearly describe how the external opportunities and threats faced by the company can be adjusted to its strengths and weaknesses. This matrix can produce four sets of possible strategic alternatives. Based on the results of the SWOT analysis, it is located at the coordinates $(-0.0636 ; 0.0435)$ of quadrant III which means that it supports a turnaround strategy, namely the company faces a very large market opportunity, but on the other hand, faces several internal constraints/weaknesses.

\section{Internal External (IE) Matrix}

While the internal - external matrix with internal values (2.1021) and external values (2.1882) in the growth stability position, namely growth through horizontal integration. The growth strategy through horizontal integration is that companies in this cell can expand market share, production facilities and technology through internal and external developments or joint ventures with other companies in the same industry. 


\section{Overall SCM strategy to get the best strategy.}

The SWOT analysis diagram shows that the company faces a huge market opportunity, but on the other hand, it faces several internal constraints/weaknesses. The focus of this strategy is to minimize the company's internal problems so that it can seize better market opportunities.

Internal External Matrix, where the company is located in the Growth Stability position, namely growth through horizontal integration. Companies in this cell can expand market share, production facilities and technology through internal and external development.

\section{CONCLUSION}

Based on the results of research and analysis of the authors, the authors draw the following conclusions:

a. By SWOT analysis Knowing the condition of Supply Chain management performance in marketing Fiberglass products of PT Eternit Gresik at this time is On the SWOT analysis map the company is located at the coordinate point $(-0.0636 ; 0.0435)$, namely in quadrant III which supports the turnaround strategy. In the Internal-External matrix, the position is GROWT STABILTY, which is the position of growth through horizontal integration. With EFAS value ( 2.1882 ) and IFAS value ( 2.1021$)$.

b. Can measure the supply chain management performance of PT Eternit Gresik's Fiberglass production in marketing by applying the AHP \& SWOT Analysis Method. On the SWOT analysis map is located at level III which means it supports a turnaround strategy, namely the company faces a very large market opportunity, but on the other hand, faced some internal constraints/weaknesses. Meanwhile, in the internal - external matrix, the internal value is in the growth stability position, namely growth through horizontal integration.

c. Can determine the alternative supply chain management strategy of PT Eternit Gresik's Fiberglass production in its marketing by applying the AHP \& SWOT analysis method. resulted in several alternative strategies as follows: Growth strategy through horizontal integration by expanding market share, production facilities and technology through internal and external development. Minimize the occurrence of the bullwhip effect, facilitate activity mapping along the value stream

\section{References}

Anatan, L., dan Ellitan, L.(2008).Supply Chain Management Teori dan Aplikasi.Alfabeta.Bandung.Kaplan, R.S., dan Norton, D.P.(1996).Balanced Scorecard Menerapkan Strategi Menjadi Aksi.Erlangga.Jakarta.Ramanathan, U., dan Gunasekaran, A., dan Subramanian, N.(2011).Supply chain Collaboration Performance Metrics: Aconceptual

Adeoye, A. O., Elegunde, A. F. (2012). Impacts of External Business Environment on Organisational Agus Maulana.

Budiarti, Isniar. 2009. Pentingnya Pengukuran Kinerja Melalui Pendekatan BalancedScorecard. Jurnal Profitabilitas. Vol. III, No. 1. Halaman 57-68

Bungin, Burhan, (2005). Penelitian Kualitatif. Jakarta : Prenada Media Group

Ciptani, Monika Kussetya. 2000. Balanced Scorecard sebagai Pengukuran Kinerja MasaDepan: Suatu Pengantar. Jurnal Akuntansi \&Keuangan. Vol. 2, No. 1. Halaman 21-35

Daft. R. L. (2010). Organization Theory and Design - 10th edition. USA: South-Westren Cengage Learning David, Fred R. (2011). Strategic Management: concepts and cases - 13th edition. NJ: Prentice Hall. Framework, Benchmarking: An International Journal Vol. 18 No. 6, 2011,856-872. 
Gaspersz, Vincent. 2011. Sistem Manajemen Kinerja Terintegrasi Balanced Scorecarddengan Malcolm Baldrige dan Lean Six Sigma Supply Chain Management. Bogor:Vinchristo Publication

Gultom, Dina R. 2009. Pengukuran Kinerja Perusahaan dengan Balanced Scorecard StudiKasus pada PT. Perkebunan Nusantara III (Persero) Medan.Skripsi.UniversitasSumatera Utara.

Kusmayadi, Dedi. 2009. Pengukuran Kinerja dengan Balanced Scorecard: Kajian Teoritis danEmpiris. Jurnal Akuntansi FE Unsil. Vol. 4, No. 1. Halaman 536-543

Luis, Suwardi dan Biromo, Prima. 2008. Step by Step in Cascading Balanced Scorecard toFunctional Scorecards. Jakarta: Gramedia Pustaka Utama

M, Porter. (2008). Strategi Bersaing, Teknik Menganalisis Industri dan Pesaing. Jakarta : Penerbit Erlangga.

Mangkunegara, A.A. Anwar Prabu. 2004. Manajemen Sumber Daya Manusia Perusahaan.Bandung: Remaja Rosdakarya

Matrix: A Case Study of an Iranian Company. Global Business and Management Research, 6(2) 150-168.

Mile,Yuldi. 2011. Pengaruh Perspektif Keuangan dan Pembelajaran terhadap KinerjaManajer Perusahaan Asuransi. Jurnal Ekonomi Bisnis. Tahun 16, No. 1. Halaman 36-43

Mirzakhani, M., Parsaamal, E., \& Golzar, A. (2014). Strategy Formulation with SWOT Mulyadi. 2009.

Sistem Terpadu Pengelolaan Kinerja Personel Berbasis Balanced scorecard.Yogyakarta: STIM YKPN

Nany, dkk., 2008. Penerapan Balanced Scorecard sebagai Pengukur Kinerja Manajemen padaRumah Sakit Umum Daerah Indramayu. Jurnal Riset Akuntansi dan Keuangan. Vol. 4,No. 1. Halaman 48-56

Nejad, M. B. (2011). Applying Topsis and QSPM Methods in Framework SWOT Model : Case Study of the Iran's Stock Market. Australian Journal of Business and Management Research, 1(5) 93103

O’Marah, K., Hofman, D. (2009). Top 25 Supply Chains. Supply Chain Management Review, 13(10) 12-19

Ommani, A. R. (2011). Strenght, Weakness, Opportunities, and Threats (SWOT) Analysis for Farming System Business Management: Case of Wheat Farmers of Shadervan District,

Pancawardani, Nurul Latifah. 2009. Pengukuran Kinerja Keuangan Perusahaan denganMetode Analisa Cash Flow Ratio. Jurnal Fokus Ekonomi. Vol. 4, No. 2. Halaman 46-59Buku[+A35

Rangkuti, Freddy. (2004). Analisis SWOT Teknik Membedah Kasus Bisnis. Gramedia Pustaka Utama Robbins,

Rivai, Veithzal dan Sagala, Ella Jauvani. 2009. Manajemen Sumber Daya Manusia untukPerusahaan dari Teori ke Praktik. Jakarta: Raja Grafindo Persada

Rusdiyanto, Ahmad Falah. 2010. Analisis Kinerja dengan Pendekatan Balanced Scorecardpada PDAM Kabupaten Semarang.Skripsi. Universitas Diponegoro. Semarang

Rusell, R. S. \& Taylor, B.W. (2009). Operations Management: Along the Supply Chain.

Sapardianto. 2013. Analisis Pengukuran Kinerja Perusahaan dengan Konsep BalancedScorecard (Studi Kasus pada PT Trustco Insan Mandiri Samarinda). eJournalAdministrasi Bisnis. Vol. 1, No. 2. Halaman 94103[14]Prasetiyatno, dkk., 2011. Pengukuran Kinerja Perusahaan dengan Metode BalancedScorecard. Jurnal Performa. Vol.10, No. 2. Halaman 71-82

Shoushtar Township, Iran. African Journal of Business Management, 5(22) 9448-9454.

Sugiyanto, Eko dan Anwar, Kasyful. 2003. Balanced Scorecard sebagai Sistem ManajemenStrategi. Jurnal Akuntansi dan Keuangan. Vol. 2, No. 1. Halaman 15-24

Sugiyono. (2014). Metode Penelitian Kuantitatif, Kualitatif, dan R\&D. Bandung: CV Afabeta.

Sugiyono. 2004. Metode Penelitian Bisnis. Bandung: Alfabeta

Suharli, Michell dan Laila, Erit. 2008. Studi Empiris terhadap Initial Return Awal: AplikasiBalanced Scorecard pada Perusahaan Publik di Jakarta. Journal of Business AppliedManagement. Vol. 1, No. 1. Halaman 77-91 
Supriadi, Yoyon. 2012. Meningkatkan Profitabilitas Perusahaan melalui Manajemen Asset.Jurnal Ilmiah Kesatuan. Vol. 14, No. 1. Halaman 33-42

Vokurka, Robert J., Zank, Gail M., Lund III, Carl M. (2002). Improving Competitiveness Through Supply Wahyuni, Sri. 2011. Analisis Balanced Scorecard sebagai Alat Pengukuran Kinerja pada PT.Semen Bosowa Maros.Skripsi. Universitas Hasanuddin.

Welas. 2012. Analisis Kinerja Keungan dengan Pendekatan Sistem Du Pont (Studi Empirikpada Perusahaan Rokok yang Sudah Go Public Periode Tahun 2000-2004). JurnalAkuntansi danKeuangan. Vol. 1, No. 1. Halaman 58-71[

Widilestari, Christine.(2011).Konsep Balanced Scorecard dan Kendala Penerapannya, Jurnal STIE Semarang, Vol 3, No 2, Edisi Juni 2011.

Wiley Schroeder, R. G. (2007). Operations Management: Contemporary Concepts and Cases Third Edition: The McGraw-Hill International Edition

Zimmermann, K., Seuring, S. (2009).Two Case Studies On Developing, Implementing and Evaluating A Balanced Scorecard in Distribution Channel Dyads,International Journal of Logistics: Research and Applications Vol. 12, No. 1, February 2009, 63-81 